\title{
CONSTITUTIONALE
}

Volume 2 Issue 1, January-June 2021: PP: 01-12

Faculty of Law, Universitas Lampung, Bandar Lampung,

Indonesia.

http://jurnal.fh.unila.ac.id/index.php/constitutionale

P-ISSN: 2723-2492 E-ISSN: 2745-9322

\section{Implementation of Children Rights Fulfilment In Bandar Lampung Special Development Institution For Childrens}

\author{
Melista Aulia Nurdina \\ aulia818@gmail.com \\ Yusticia Institute, Indonesia
}

Submitted: 19 January 2021; Reviewed: 2 February 2021; Accepted: 9 April 2021

\begin{tabular}{|c|c|}
\hline Article's Information & Abstract \\
\hline $\begin{array}{l}\text { Keywords: Methods; Implementation; Children. } \\
\text { DOI: } \\
\text { https://doi.org/10.25041/constitutionale.v2i1.2254 }\end{array}$ & $\begin{array}{l}\text { Protection of children faced in } \\
\text { conflict with the law and undergoing } \\
\text { a criminal period in the Special } \\
\text { Development Institution for Children, } \\
\text { their rights and needs must always be } \\
\text { fulfilled. These children's rights } \\
\text { consist of the right to education, skills } \\
\text { guidance, health care, and others. } \\
\text { This study aims to identify and } \\
\text { analyze the fulfillment of children's } \\
\text { rights that must be fulfilled in the } \\
\text { Special Development Institution for } \\
\text { Children. The problem in this } \\
\text { research is children's rights that must } \\
\text { be fulfilled in the Special } \\
\text { Development Institution for Children. } \\
\text { The method of implementing the } \\
\text { fulfillment of children's rights in the } \\
\text { Special Development Institute for } \\
\text { Children, factors that hinder the } \\
\text { implementation of the fulfillment of } \\
\text { rights in the Special Development } \\
\text { Institution for Children. The } \\
\text { approach to the problem used in this } \\
\text { research is normative and empirical } \\
\text { juridical. The data analysis in this } \\
\text { study was conducted qualitatively. } \\
\text { This study found that the rights of } \\
\text { children in the Class II of Bandar }\end{array}$ \\
\hline
\end{tabular}




Lampung Special Development
Institution have been carried out
well. The assisted children get formal
and non-formal education; the
assisted children receive self-
development guidance such as hair
shaving, electric welding, planting,
and mind preservation. The assisted
children are also free to play music,
exercise, and perform worship
according to their respective beliefs.
Implementing the fulfillment of
children's rights uses an individual
approach, and its implementation
uses an assessment. Officers have
programs to fulfill children's rights,
such as service, guidance,
implementation, and supervision. The
author suggests that Class II of
Bandar Lampung Special
Development Institute's officers can
fulfill children's rights ranging from
formal education, non-formal
education, skills, self-development,
religion, maximizing the individual
approach method to assisted children
so that they can know more about the
backgrounds, needs, emotions and
interests of these children, as well as
improve the quality of existing advice
and infrastructure.

\section{A. Introduction}

Indonesia is a constitutional state as stipulated in Article 1 Paragraph (3) of the 1945 Constitution of the Republic of Indonesia. A constitutional state's characteristics are upholding and recognizing human rights, both adults and children, who receive treatment for rights. The same Human Rights. ${ }^{1}$ Children are a gift from God Almighty, who must always be loved and cared for wholeheartedly. Children are also the foundation of a nation where the nation's future is determined by the children who will replace the previous generation in leading this nation. However, not all children can become children who can provide examples of good behavior for other children. Some children have deviant behavior, which in law is familiar as Juvenile Delinquency. ${ }^{2}$ Social development at this time affects children's emotions. Research shows that children who come from disharmonious or divorced families

\footnotetext{
1 Narvedha Andriyana, "POLA PEMBINAAN ANAK DIDIK PEMASYARAKATAN DI LEMBAGA PEMBINAAN KHUSUS ANAK KELAS I KUTOARJO,” Jurnal Komunikasi Hukum (JKH), vol. 6, 2020, https://ejournal.undiksha.ac.id/index.php/jkh/article/view/28348.

2 Tri Andrisman, Hukum Peradilan Anak, Bandar Lampung, Fakultas Hukum Universitas Lampung, 2013. pg. 3.
} 
tend to have bad behavior. This happens because of parents' lack of affection and causes children's behavior that is not following applicable norms. ${ }^{3}$ The problem of children dealing with the law is crucial because children are victims of the crime itself, resulting in unstable emotions or self-control. ${ }^{4}$ It can be assumed that many factors influence a child to commit a criminal act. The child's behavior tends to be critical, aggressive, and shows anti-social traits, which can be why the behavior originates. ${ }^{5}$ Of course, this is of concern to many parties because children can already commit acts that endanger others and become criminal acts such as stealing, snatching, and raping.

Fulfilling children's rights is an obligation for all nation components, especially law enforcement officers, as mandated by law. One of the serious and urgent problems to get attention is handling children in conflict with the law or children in conflict with the law. ${ }^{6}$ Based on Law Number 11 of 2012 concerning the Juvenile Criminal Justice System, Article 1 paragraph (3) explains that legal sanctions for a criminal act committed by a child are subject to their age provisions. ${ }^{7}$ Children who are 12 (twelve) years old but who are not yet 18 (eighteen) years old who are suspected of committing a criminal act are called Children Conflicting with the law. Article 21 paragraph (1) explains that a child who commits a criminal act but is under 12 years of age will be handed over to his parents or can be included in a coaching, guidance, and education program at the Social Welfare Organizing Institution or Lembaga Penyelenggaraan Kesejahteraan Sosial (LPKS) or other government agencies that handle the social welfare sector both at national and regional levels in a maximum of 6 (six) months. Article 32 paragraph (2) describes the detention and imposition of crimes for children who are 14 (fourteen) years old or more and are suspected of committing a criminal act with the threat of imprisonment of 7 (seven). Imprisonment is given to a child who commits a severe crime, of which if an adult commits the act, it will also be considered a violation of the law or a crime and will be subject to sanctions. ${ }^{8}$ The Special Development Institution for Children is a forum so that children dealing with the law can be properly nurtured. When the criminal court is over, it is hoped that children in conflict and face the law will become better individuals and not get physical, psychological, or sexual violence from children. Others or employees of the institution. ${ }^{9}$

However, children are still children who always need more affection and special treatment. Therefore, the criminal justice system applied to children is different from the criminal justice system in general. This difference is made so that children's rights can always be fulfilled. This right must always be implemented in parallel with the juvenile criminal

\footnotetext{
${ }^{3}$ Muliana, "Perkembangan Perilaku Anak Dari Keluarga Yang Bercerai Di Kecamatan Ulim Kabupaten Pidie Jaya," Jurnal, Banda Aceh, Universitas Syiah Kuala Darussalam, accessed February 1, 2021, https://media.neliti.com/media/publications/187079-ID-perkembangan-sosial-emosional-anak-dari.pdf.

4 Maya Atikasuri, Henny Suzana Mediani, and Nita Fitria, "Tingkat Kecemasan Pada Andikpas Usia 14-18 Tahun Menjelang Bebas Di Lembaga Pembinaan Khusus Anak Kelas II,” Journal of Nursing Care 1, no. 1 (February 12, 2018): 78, https://doi.org/10.24198/jnc.v1i1.15773.

${ }^{5}$ Nikmah Rosidah, Budaya Hukum Hakim Anak di Indonesia, Semarang, Pustaka Magister Semarang, 2014. pg 4.

${ }^{6}$ Eddy Rifai, Perspektif Keadilan Restoratif dalam Peradilan Pidana Anak, Bandar Lampung, Fakultas Hukum Universitas Lampung, 2012,pg. 2.

${ }^{7}$ Ria Juliana and Ridwan Arifin, "Anak Dan Kejahatan (Faktor Penyebab Dan Perlindungan Hukum)," Jurnal Selat 6, no. 2 (August 26, 2019): 225-34, https://doi.org/10.31629/selat.v6i2.1019.

8 Purniati, Mamik Sri Supatmi dan Ni Made Martini Tinduk, mengutip Harry E. Allen and Clifford E. Simmonsen, dalam Correction in America: An Introduction, Analisa Situasi Sistem Peradilan Pidana Anak (Juvenile Justice System) di Indonesia, UNICEF, Indonesia, 2003, pg.2.

${ }^{9}$ Eka Intan et al., "BEGAL ANAK; PEMENUHAN HAK DAN LEMBAGA PEMBINAAN KHUSUS ANAK KELAS II A BANDAR LAMPUNG FULFILLMENT OF THE RIGHTS OF THE CHILD IN THE CLASS II SPECIAL CHILD COACHING INSTITUTION IN BANDAR LAMPUNG," Cepalo 2, no. 2 (September 12, 2018): 45-84, https://doi.org/10.25041/cepalo.v2no2.1764.
} 
justice system. Children can continue to have an everyday life that always gets education, love, and time to develop themselves. Children also get coaching and guidance to realize that what they are doing is a mistake and can accept themselves, which usually means that children will lose their self-confidence because they are serving criminal sentences in the Special-Development Institution for Children. ${ }^{10}$ Therefore, to avoid retaliation, a restorative approach must be implemented because it focuses on recovery rather than retaliation. Article 3 of Law Number 11 of 2012 concerning the Juvenile Criminal Justice System states that the rights of every child who are currently in the judicial process explain what the rights of the child must be implemented for every child who faces or has problems with the law, class being treated with compassionate or humanly, where the execution of the punishment is separated from adults, conducts activities that can increase the feeling of pleasure and comfort such as recreational activities, does not receive mental, physical or inhuman torture such as violence, receive proper education such as formal education and non-formal education, get adequate health care and other rights stated in the regulations or other applicable laws.

Children's survival is not only listed in the particular law that regulates children, but the highest norm in Indonesia, which is the 1945 Constitution of the Republic of Indonesia (UUD NRI 1945) in Article 28B Paragraph (2) has stated that every child has the right to survival, to be protected from violence and discrimination and have the right to protection. These rights are used as a reference for special laws on children, one of which is Law Number 11 of 2012 concerning the Juvenile Criminal Justice System to always protect children's rights for children who conflict with the law. Therefore, these rights must always be fulfilled because children have different thoughts from adults in that they still have to develop physically and psychologically. The method of implementing the fulfillment of ideal children's rights in the Special Development Institute for Children is expected to make these children realize their mistakes, improve themselves, and as a deterrent effect for them not to repeat criminal acts and also improve their quality so that they can be accepted back into the community, without having to feel discrimination from the community, has a role in continuing the dream of the nation and state, and play an active role in learning activities. ${ }^{11}$ Apart from these things, assistance from adults is mandatory because children cannot realize children's rights themselves. Therefore, parents, society, and the government's role is an important role to fulfill the implementation model of children's rights in the Special Development Institutions for Children and to protect these rights so that they are always fulfilled wherever the child is. ${ }^{12}$ Currently, there are still children's rights in LPKA that have not been fulfilled.

The problems in this research are what are the rights of children that must be fulfilled in the Special Development Institution for Children; What is the method of implementing the fulfillment of children's rights in the Special Development Institution for Children; What are the factors that hinder the fulfillment of rights in the Special Development Institution for Children. This type of research used in this research is normative and empirical juridical. The resource persons in this study consisted of the Head of the Correctional Division of the Regional Office of the Ministry of Law and Human Rights in Lampung, the Head of Development and the Head of the Sub-Section for Education and Community Guidance and

\footnotetext{
10 Muhammad Agung Adynatha Politeknik Ilmu Pemasyarakatan J1 Raya Gandul No et al., "SIKAP PENERIMAAN ANAK DI LEMBAGA PEMBINAAN KHUSUS ANAK KELAS II JAKARTA,” 2020, https://doi.org/10.31604/justitia.v7i1.380-389.

11 Yuliyanto Yuliyanto, "Pembinaan Anak Yang Berkonflik Dengan Hukum Di Lembaga Pembinaan Khusus Anak Kelas II Bandung," Jurnal Penelitian Hukum De Jure 20, no. 1 (March 23, 2020): 103, https://doi.org/10.30641/dejure.2020.v20.103-116.

12 Christian Rambitan, "TUGAS DAN FUNGSI LEMBAGA PEMASYARAKATAN DALAM MEREHABILITASI ANAK YANG SEDANG MENJALANI HUKUMAN," LEX ET SOCIETATIS, vol. 1, August 16, 2013, https://ejournal.unsrat.ac.id/index.php/lexetsocietatis/article/view/2450.
} 
Child Alleviation or Bimbingan Kemasyarakatan dan Pengentasan Anak (BIMKEMAS), the Special Development Institution for Class II Children of Bandar Lampung, Children of the Occupants of the Class II Special Development Institution for Children in Bandar Lampung, Director of the Lampung Child Advocacy Institute, and Academics of Criminal Law Masters of Law, University of Lampung. The data analysis in this study was conducted qualitatively.

\section{B. Discussion}

\section{Children's Rights in Special Development Institutions for Children}

LPKA students are 12 (twelve) years old but not yet 18 (eighteen) years old. ${ }^{13}$ The rights of assisted children as written in the background in Article 3 of Law Number 11 of 2012 concerning the Juvenile Criminal Justice System for Children, there are also children's rights that must be fulfilled for children serving a criminal period the Special Child Development Institution. The assisted children's rights are written in Article 4 Paragraph (1) of Law Number 11 of 2012 concerning the Juvenile Criminal Justice System. ${ }^{14}$ This explains that the child has the right to get or get a reduced sentence, get the process of assimilating society, get time to visit family, get conditions for leave, get conditions for conditional freedom, and other rights in implemented regulations.

Besides, Article 85 of Law Number 11 of 2012, which regulates the Juvenile Criminal Justice System which contains the rights of children that must be fulfilled while serving a criminal period in the Special Child Development Institution, explains that children are in conflict or are dealing with the law are obliged to serve his sentence and be placed in the Special Development Institution for Children. Children who conflict with the law and undergo their criminal period must also retain their proper rights, such as receiving formal education, mentoring, mentoring, skills training, supervision, and the program is carried out under the Correctional Center's supervision. The Correctional Center, commonly known as Balai Permasyarakatan or (BAPAS), aims to strengthen an institution including the Special Development Institution for Children, to fulfill the child's best interests while undergoing a criminal period. ${ }^{15}$

The rights of assisted children that have been fulfilled in the Class II Bandar Lampung Special Development Institution under Article 85 of Law Number 11 of 2012 can be explained in detail as follows.

a. Children who receive criminal penalties are required to serve a criminal period in the LPKA or the Special Child Development Institution;

The Class II Special Development Institute in Bandar Lampung is a place for coaching institutions for children undergoing a criminal period where the children are separated from adults and get guidance according to their needs. Before entering the Special Development Institution for Children, the assisted children will conduct an assessment to find out information about the child such as age, school, and their needs, which will later become a reference for guidance.

\footnotetext{
${ }_{13}$ Agnes Widya Pangestika and Nunung Nurwati, "FUNGSI LEMBAGA PEMBINAAN KHUSUS ANAK DALAM MELAKSANAKAN PROGRAM PEMBINAAN BERBASIS BUDI PEKERTI PADA ANAK DIDIK PEMASYARAKATAN," n.d.

${ }^{14}$ Ni Made et al., "IMPLEMENTASI UNDANG-UNDANG NOMOR 11 TAHUN 2012 TENTANG SISTEM PERADILAN PIDANA ANAK TERHADAP CURANMOR YANG DILAKUKAN OLEH ANAK DI KABUPATEN BULELENG (STUDI KASUS PERKARA NOMOR: B/346/2016/RESKRIM)," Tahun, vol. 2, September 24, 2019, https://doi.org/10.23887/JATAYU.V2I2.28776.

${ }^{15}$ Okky Chahyo Nugroho, "Peran Balai Pemasyarakatan Pada Sistem Peradilan Pidana Anak Ditinjau Dalam Perspektif Hak Asasi Manusia," Jurnal HAM 8, no. 2 (December 15, 2017): 161, https://doi.org/10.30641/ham.2017.8.161-174.
} 
b. Children who undergo a criminal period in a guidance institution are obliged to and have the right to receive guidance, supervision, receive education according to their needs, training, and self-development

Fostered children still get formal and non-formal education under what they need because the guidance institution already has classes for learning, in collaboration with educational foundations and officers who help teach the assisted children. ${ }^{16}$ Not only formal education, but the assisted children also receive non-formal education such as spiritual education and training according to their interests and talents such as barber, electric welding, ornamental plant nurseries, and others.

c. The Special Development Institution for Children is also obliged to provide education, training, guidance, and the fulfillment of other rights for assisted children;

The Class II Bandar Lampung Special Development Institute has organized well for education in collaboration with the Dwi Mulya Natar Education Foundation. Every day, the assisted children go to school and wear their usual uniform. The assisted children also received training in ornamental plant nurseries in collaboration with Lampung State Polytechnic and handicraft training in collaboration with CV. Fajar Semidang Lampung also empowers officers who have special skills such as barber, electric welding, or other things taught to the assisted children. Approximately 90 assisted children received assimilation and integration to prevent and control the spread of the Covid-19 virus. Assisted children who receive assimilation and integration must also comply with the applicable terms and conditions following the Decree of the Minister of Law and Human Rights Number M.HH19.PK.01.04.04 of 2020 regarding the prevention of the Covid-19 virus. The conditions for assisted children to obtain assimilation and integration are children whose prison terms are $1 / 2$ (half) until December 31, 2020. They are not children related to Government Regulation of the Republic of Indonesia Number 99 of 2012 concerning the Second Amendment to Government Regulation Number 32 of 1999 concerning Terms And Procedures for Implementing the Rights of Correctional Assisted Citizens and not undergoing subsidies and not foreigners.

\section{Methods of Implementing the Fulfillment of Children's Rights in Special Development Institutions for Children}

The fulfillment of children's rights in the Class II Bandar Lampung Special Development Institution is carried out using the guidance method using the individual approach method itself, carried out by assessing each child to obtain more in-depth information about the assisted children and their backgrounds. ${ }^{17}$ After approaching, the officer as a supervisor or facilitator for the assisted children has specific programs to fulfill the fulfillment of children's rights in the Class II Special-Development Institution of Bandar Lampung so that it is always fulfilled and the assisted children do not feel deprived at all. If the child's rights are adequately fulfilled, the officers' guidance and supervision will also be well absorbed and accepted by the assisted children. The programs in question are as follows:

a. Service

As a supervisor for the assisted children in the guidance institution, the officer provides general services such as mentoring, coaching, providing and supervising educational activities by monitoring ongoing teaching and learning activities. Officers also provide conditional

\footnotetext{
${ }^{16}$ Fransiska Novita Eleanora and Esther Masri, "Tinjauan Yuridis Pembinaan Anak Di Lembaga Pembinaan Khusus Anak (LPKA) Tangerang," Jurnal Kajian Ilmiah 18, no. 3 (September 15, 2018): 215, https://doi.org/10.31599/jki.v18i3.266.

${ }^{17}$ Interview with Siun Samirin, as Head of Sub-Division of Education and BIMKEMAS on July 6, 2020.
} 
services such as referral of assisted children who are seriously ill to get treatment at the hospital or request children to get a routine counseling schedule. ${ }^{18}$

b. Guidance

The Class II Bandar Lampung Special Development Institute's guidance is carried out by directly bringing in a person or group of experts in these fields. After that, the assisted children will be free to choose which work guidance they like or according to their talents. The Class II Bandar Lampung, Special Development Institute, has various kinds of work guidance such as ornamental plant nurseries, woodcraft making, electric welding, barber or hair shaving skills that officers and other useful guidance can teach to fill the free time of assisted children with activities which they can apply and make money outside of the coaching agency.

c. Supervision

Supervision by officers is in the form of evaluation and monitoring or monitoring. ${ }^{19}$ Officers carry out routine supervision so that children's rights in Special Development Institute of Bandar Lampung are always fulfilled. Officers will supervise how to prepare learning and teaching activities for children, supervision in providing food that is always healthy and nutritious under applicable regulations, provision of drinking water in every place, and supervising the guidance and teaching of formal and non-formal education with officers who always monitor it. ${ }^{20}$ The supervision is routinely carried out so that the assisted children are always fulfilled in the aspects of life and development, which have 9 (nine), such as getting food, getting a decent place to live, getting clean water, getting adequate health facilities, giving free time, implementing cultural activities for assisted children, receive information and news that is appropriate for their age and events that occur, receive protection for their dignity and self-respect. ${ }^{21}$

d. Implementation

The officers carry out the fulfillment of children's rights in the Bandar Lampung Class II Special Development Institution following children,s rights contained in the applicable law. Assisted children receive education according to their age and needs, with officers always supervising and monitoring teaching and learning activities. The officers also brought in teachers from the Dwi Mulya Foundation, Pesawaran Lampung Regency and to teach the assisted children. The officer uses an individual approach to determine what talents the child has so that the assisted child can develop his talents according to the things he is interested in. Children's rights that must be fulfilled are the right to perform worship according to their respective beliefs. The officers carry out this by establishing religious programs such as daily coaching for congregational prayers for Muslims and daily reading of the Bible for those who are Christians. ${ }^{22}$

The officers also carry out a weekly religious program, consisting of spirituality and Islamic religious education, carried out every week by bringing ustadza-ustadz from the Al-Qirom Hajimena Islamic Boarding School, Pesawaran District, Lampung. Religious programs for Christianity as in services, are also held every week with officers who have prepared candles,

\footnotetext{
${ }^{18}$ Interview with Auda Irwanda, as Head of Coaching on July 6, 2020.

${ }^{19}$ Eka Rista Harimurti, "Manajemen Pembinaan Anak Di Lembaga Pembinaan Khusus Anak Klas II Jakarta Dalam Rangka Perlindungan Hak Anak Pidana," JURNAL ILMIAH WAHANA PENDIDIKAN 5, no. 3 (August 6, 2019): 23-32, https://doi.org/10.5281/zenodo.3360407.

${ }^{20}$ Wawancara dengan oleh Auda Irwanda, selaku Kasi Pembinaan pada tanggal 6 Juli 2020.

${ }^{21}$ Rifky Taufiq Fardian and Meilanny Budiarti Santoso, "PEMENUHAN HAK ANAK YANG BERHADAPAN (BERKONFLIK) DENGAN HUKUM DI LEMBAGA PEMBINAAN KHUSUS ANAK (LPKA) KELAS II BANDUNG," Jurnal Kolaborasi Resolusi Konflik 2, no. 1 (April 22, 2020): 7, https://doi.org/10.24198/jkrk.v2i1.27043.

${ }^{22}$ Interview with Siun Samirin, as Head of Sub-Division of Education and BIMKEMAS on July 6, 2020.
} 
Bibles, and musical instruments needed to accompany prayers. ${ }^{23}$ Assisted children can also convey complaints or discomfort by counseling with officers. The assisted children will come alone or based on the referral they have given to the officer. The counseling will be carried out to find out what complaints the assisted children feel and look at the above's psychological side to overcome them. After that, further counseling will be carried out if needed. The results of this counseling will be discussed with other officers with doctors, and rehabilitation officers to find solutions to problems with complaints from assisted children. Education, training, coaching, and guidance carried out during the child's criminal period aim to change attitudes and mindsets and increase a sense of responsibility or commonly referred to as a criminal goal. ${ }^{24}$

\section{Inhibiting Factors in the Implementation of the Fulfillment of Children's Rights in Special Child Development Institutions}

According to Soerjono Soekanto, there are factors inhibiting law enforcement, including factors that come from the law itself or laws, factors that come from law enforcers, factors that come from insufficient facilities and facilities, factors that come from the community or the surrounding environment, and factors that comes from culture. ${ }^{25}$ Law enforcement to fulfill children's rights in the Special Development Institution for Class II Children in Bandar Lampung also has inhibiting factors, as follow:

a. Legal Factors

The first factor that becomes an obstacle in implementing the fulfillment of children's rights in the Special Development Institution for Children, of course, comes from the law itself. The implementation of the fulfillment of children's rights in the Special Development Institution for Children has obstacles because there is no official procedure or appropriate technical implementation to fulfill the assisted children's rights.

b. Law Enforcement Factors

The next inhibiting factor is the law enforcer factor, which in the Special Development Institution for Class II Bandar Lampung Children are its officers. There are 94 officers in the guidance institution, with 83 male and 11 female. The officers' quality is an inhibiting factor because only 12 of them are law graduates from higher education. Special Development Institution for Children also needs officers who have a background in counseling or psychology to know the assisted children's mentality. This is because officers facilitate the assisted children in exercising their rights as assisted children in the development institution and as a means for children to express themselves to others. ${ }^{26}$ However, the officers in the Special Development Institution for Children have more and more high school backgrounds. Therefore, officers who have a legal and psychological basis are needed to handle the assisted children to comply with the applicable law and pay attention to the assisted children's psychology. ${ }^{27}$

c. Facility and Infrastructure Factors

Further inhibiting factors are the inadequate facilities and facilities at the Class II Bandar Lampung Special Development Institution for Children, such as lack of reading material in

\footnotetext{
${ }^{23}$ Interview with Siun Samirin, as Head of Sub-Division of Education and BIMKEMAS on July 6, 2020.

${ }^{24}$ Erna Dewi, Sistem Minimum Khusus Dalam Hukum Pidana (Sebagai Salah Satu Usaha Pembaharuan Hukum Pidana Indonesia, Semarang, Pustaka Magister Semarang, 2011, pg. 34.

${ }^{25}$ Soerjono Soekanto, Faktor-Faktor yang Memengaruhi Penegakan Hukum, Jakarta, Raja Grafindo Persada. 2007.pg 5.

${ }^{26}$ Robert L.Gibson, Marianne H.Mitchell, Bimbingan Dan Konseling, Yogyakarta, Pustaka Pelajar, 2010, pg. 215

${ }^{27}$ Interview with Dr. Ahmad Irzal Fardiansyah, as Academic of Criminal Law Master of Law, University of Lampung, July 30, 2020.
} 
the library, lack of musical instruments for assisted children who have musical talent, lack of sports equipment for assisted children who like sports and also lack adequate facilities and facilities for skills training carried out within the coaching institutions. Skills training requires special and trained experts to teach the assisted children about the skills they have. The minimal budget is an obstacle for the Special Development Institution for Children to improve its facilities and infrastructure,

d. Society Factors

The community is one of the things that hinder the implementation of the fulfillment of children's rights in the Special Development Institution for Children, which has the most significant impact because, if the assisted children in the Special Development Institution for Children have received rights according to their needs, get the best development and guidance and also make them better children, however, if the community still looks at these children with disdain and remain distinct, the assisted children will feel the coaching institution is useless because the society's stigma still considers them spoiled children.

This, of course, can be avoided if the community can accept back the fostered children who have finished their criminal period without having to look at them with disdain. The social environment dramatically influences the Child Special Development Institute's success rate in fulfilling children's rights and providing guidance and coaching. As Soerjono Soekanto stated, the social environment will significantly influence the growth of a child's motivation and success. The social environment that significantly influences it consists of parents, relatives, and siblings such as siblings and cousins, groups of playmates, games, peers or friends at school, and educator groups, class teachers who teach at schools. ${ }^{28}$

e. Cultural Factors

The last factor that becomes the inhibiting factor is the cultural factor that initially originates from the fostered children themselves. The low level of education and the lack of awareness of the assisted children causes the rights and guidance they get in the Class II Special Development Institution of Bandar Lampung not optimal. ${ }^{29}$ The Covid-19 pandemic that occurred in Indonesia was also one factor inhibiting the implementation of the fulfillment of children's rights in the Class II Special Development Institute of Bandar Lampung. The Covid-19 pandemic became an obstacle because it stopped many activities and reduced the Bandar Lampung Class II Special Development Institution budget. ${ }^{30}$

\section{Conclusion}

Based on the research and discussion results, what happened at the Class II Special Development Institute in Bandar Lampung, the authors can conclude as follows.

1. Children's rights in the Class II Special Development Institution of Bandar Lampung have been carried out well. The assisted children receive formal and non-formal education, assisted children to receive personal development guidance such as hair shaving, electric welding, and plant cultivation. The assisted children are also free to play music, perform worship according to their respective beliefs.

2. Implementing the fulfillment of children's rights in Class II Bandar Lampung Special Development Institution uses a particular method approach uses an assessment to determine the child's background, emotions, and interests. Officers also have programs to fulfill children's rights, class service, guidance, implementation, and supervision.

\footnotetext{
${ }^{28}$ Soerjono Soekanto, Sosiologi Suatu Pengantar, Jakarta, PT Raja Grafindo Persada, 2017. pg 386.

${ }^{29}$ Interview with Farid Junaedi, Head of the Corrections Division of the Ministry of Law and Human Rights in Bandar Lampung, June 23, 2020.

${ }^{30}$ Interview with Siun Samirin, as Head of Sub-Division of Education and BIMKEMAS on July 6, 2020.
} 


\section{Advice}

This research suggestion is addressed to all people who are assigned in the Class II Bandar Lampung Special Development Institution so they can fulfill children's rights starting from formal education, non-formal education, skills, self-development, religion, and health, which refers to Law Number 11 of 2012 concerning the Juvenile Criminal Justice System. Firstly, the officers of the Class II Bandar Lampung Special Development Institute to maximize the individual approach method to the assisted children so that they can know more about the children's backgrounds, needs, emotions, and interests. Secondly, it is hoped that the Class II Bandar Lampung Special Development Institution can maximize the facilities and infrastructure for the assisted children and also introduce the assisted children to the community so that the stigma of society in the assisted children can change.

\section{A. Books}

\section{Bibliography}

Andrisman, Tri. Hukum Peradilan Anak, Bandar Lampung, Bandar Lampung: Fakultas Hukum Universitas Lampung. 2013.

Dewi, Erna,, Sistem Minimum Khusus Dalam Hukum Pidana (Sebagai Salah Satu Usaha Pembaharuan Hukum Pidana Indonesia), Semarang: Pustaka Magister Semarang. 2011.

Gibson, Robert L., Marianne H.Mitchell, Bimbingan Dan Konseling, Yogyakarta: Pustaka Pelajar. 2010

Rosidah, Nikmah, Budaya Hukum Hakim Anak di Indonesia, Semarang: Pustaka Magister Semarang. 2014.

Seokanto, Soerjono, Faktor-Faktor yang Memengaruhi Penegakan Hukum, Jakarta: Raja Grafindo Persada. 2007

Seokanto, Soerjono. Sosiologi Suatu Pengantar. Jakarta: PT Raja Grafindo Persada. 2017.

\section{B. Journal}

Agung Adynatha Politeknik Ilmu Pemasyarakatan J1 Raya Gandul No, Muhammad, Gandul Kec Cinere, Kota Depok, and Jawa Barat ABSTRAK. "SIKAP PENERIMAAN ANAK DI LEMBAGA PEMBINAAN KHUSUS ANAK KELAS II JAKARTA," 2020. https://doi.org/10.31604/justitia.v7i1.380-389.

Andriyana, Narvedha. "POLA PEMBINAAN ANAK DIDIK PEMASYARAKATAN DI LEMBAGA PEMBINAAN KHUSUS ANAK KELAS I KUTOARJO." Jurnal

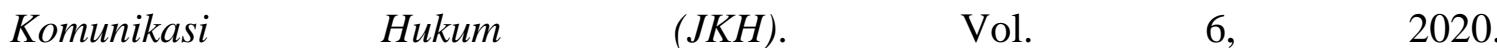
https://ejournal.undiksha.ac.id/index.php/jkh/article/view/28348.

Atikasuri, Maya, Henny Suzana Mediani, and Nita Fitria. "Tingkat Kecemasan Pada Andikpas Usia 14-18 Tahun Menjelang Bebas Di Lembaga Pembinaan Khusus Anak Kelas II." Journal of Nursing Care 1, no. 1 (February 12, 2018): 78. https://doi.org/10.24198/jnc.v1i1.15773.

Eleanora, Fransiska Novita, and Esther Masri. "Tinjauan Yuridis Pembinaan Anak Di Lembaga Pembinaan Khusus Anak (LPKA) Tangerang.” Jurnal Kajian Ilmiah 18, no. 3 (September 15, 2018): 215. https://doi.org/10.31599/jki.v18i3.266.

Fardian, Rifky Taufiq, and Meilanny Budiarti Santoso. "PEMENUHAN HAK ANAK YANG BERHADAPAN (BERKONFLIK) DENGAN HUKUM DI LEMBAGA PEMBINAAN KHUSUS ANAK (LPKA) KELAS II BANDUNG.” Jurnal Kolaborasi Resolusi Konflik 2, no. 1 (April 22, 2020): 7. https://doi.org/10.24198/jkrk.v2i1.27043.

Harimurti, Eka Rista. "Manajemen Pembinaan Anak Di Lembaga Pembinaan Khusus Anak 
Klas II Jakarta Dalam Rangka Perlindungan Hak Anak Pidana." JURNAL ILMIAH WAHANA PENDIDIKAN 5, no. 3 (August 6, 2019): 23-32. https://doi.org/10.5281/zenodo.3360407.

Intan, Eka, Putri Lembaga, Konsultan Bantuan, and Hukum Intan. "BEGAL ANAK; PEMENUHAN HAK DAN LEMBAGA PEMBINAAN KHUSUS ANAK KELAS II A BANDAR LAMPUNG FULFILLMENT OF THE RIGHTS OF THE CHILD IN THE CLASS II SPECIAL CHILD COACHING INSTITUTION IN BANDAR LAMPUNG." $\begin{array}{lllllll}\text { Cepalo 2, no. } 2018 \text { ): } & 2 \text { (September } & \text { 45 }\end{array}$ https://doi.org/10.25041/cepalo.v2no2.1764.

Juliana, Ria, and Ridwan Arifin. "Anak Dan Kejahatan (Faktor Penyebab Dan Perlindungan Hukum)." Jurnal Selat 6, no. 2 (August 26, 2019): 225-34. https://doi.org/10.31629/selat.v6i2.1019.

Made, Ni, Ita Ariani, Ni Putu, Rai Yuliartini, Dewa Gede, and Sudika Mangku. "IMPLEMENTASI UNDANG-UNDANG NOMOR 11 TAHUN 2012 TENTANG SISTEM PERADILAN PIDANA ANAK TERHADAP CURANMOR YANG DILAKUKAN OLEH ANAK DI KABUPATEN BULELENG (STUDI KASUS PERKARA NOMOR : B/346/2016/RESKRIM)." Tahun. Vol. 2, September 24, 2019. https://doi.org/10.23887/JATAYU.V2I2.28776.

Muliana. "Perkembangan Perilaku Anak Dari Keluarga Yang Bercerai Di Kecamatan Ulim Kabupaten Pidie Jaya." Jurnal, Banda Aceh, Universitas Syiah Kuala Darussalam. Accessed February 1, 2021. https://media.neliti.com/media/publications/187079-IDperkembangan-sosial-emosional-anak-dari.pdf.

Nugroho, Okky Chahyo. "Peran Balai Pemasyarakatan Pada Sistem Peradilan Pidana Anak Ditinjau Dalam Perspektif Hak Asasi Manusia.” Jurnal HAM 8, no. 2 (December 15, 2017): 161. https://doi.org/10.30641/ham.2017.8.161-174.

Pangestika, Agnes Widya, and Nunung Nurwati. "FUNGSI LEMBAGA PEMBINAAN KHUSUS ANAK DALAM MELAKSANAKAN PROGRAM PEMBINAAN BERBASIS BUDI PEKERTI PADA ANAK DIDIK PEMASYARAKATAN," n.d.

Rambitan, Christian. "TUGAS DAN FUNGSI LEMBAGA PEMASYARAKATAN DALAM MEREHABILITASI ANAK YANG SEDANG MENJALANI HUKUMAN." LEX ET $\begin{array}{llllll}\text { SOCIETATIS. } & \text { Vol. } & 1, & \text { August } & 16, & \end{array}$ https://ejournal.unsrat.ac.id/index.php/lexetsocietatis/article/view/2450.

Sudarsono, Jovita Guntara. "PENGARUH VISUAL MERCHANDISING TERHADAP IMPULSE BUYING MELALUI POSITIVE EMOTION PADA ZARA SURABAYA." Jurnal Manajemen Pemasaran 11, no. 1 (April 1, 2017): 16-25. https://doi.org/10.9744/pemasaran.11.1.16-25.

Yuliyanto, Yuliyanto. "Pembinaan Anak Yang Berkonflik Dengan Hukum Di Lembaga Pembinaan Khusus Anak Kelas II Bandung." Jurnal Penelitian Hukum De Jure 20, no. 1 (March 23, 2020): 103. https://doi.org/10.30641/dejure.2020.v20.103-116.

\section{Law and Other Regulations}

1945 Constitution;

Law Number 12 of 1995 concerning Corrections;

Law Number 35 of 2014 concerning Child Protection;

Law Number 11 of 2012 concerning the Juvenile Criminal Justice System

Decree of the Minister of Law and Human Rights Number M.HH-19.PK.01.04.04 of 2020 regarding the Prevention of the Covid-19 Virus. 
